\title{
PENGEMBANGAN PARIWISATA MELALUI NILAI BUDAYA BERWAWASAN LINGKUNGAN BUDAYA, PARADIGMA BARU SIMBIOSIS MUTUALISME
}

\author{
Roro Dewi Sulistyowati \\ Sekolah Tinggi Pariwisata AMPTA Yogyakarta \\ Email: rrdsulistyowati@stpampta.ac.id
}

\begin{abstract}
ABSTRAK
Budaya sangat erat kaitannya dengan pariwisata, karena bisa kita lihat dari definisi Budaya yang merupakan simbol masyarakat sekitar yang di sekitar lingkungan terdapat makna yang mencakup segala hal yang merupakan hasil cipta, karya manusia. Sedangkan Pariwisata merupakan rangkaian perjalanan yang di lakukan oleh seseoarang atau kelompok orang diluar tempat tinggalnya yang bersifat sementara untuk berbagai tujuan (seperti berlibur, menikmati keindahan alam dan budaya, bisnis, dan lain-lain. Kemudian dapat kita ketahui bahwa hubungan antara budaya memiliki hubungan yang sangat erat kaitannya dengan Pariwisata dan lingkungan budaya yang dapat memberikan nilai lebih bagi wisatawan yang datang untuk berkunjung ke tempat tersebut. dapat juga kita simpulkan bahwa pariwisata dan budaya merupakan aktivitas pertukaran informasi dan simbol-simbol budaya yang di dalamnya terdapat tempat, tradisi, kesenian, upacara, dan identitas yang lainnya yang terdapat di tempat tersebut untuk dapat dinikmati oleh setiap wisatawan yang datang berkunjung.

Kata kunci: Pengembangan pariwisata, nilai budaya, lingkungan budaya.
\end{abstract}

\begin{abstract}
Culture is very closely related to tourism, because we can see from the definition of culture which is a symbol of the surrounding community around which there is a meaning that includes everything that is the result of creation, human work. Meanwhile tourism is a series of trips undertaken by a person or group of people outside their temporary residence for various purposes (such as vacationing, enjoying the beauty of nature and culture, business, etc. Then we can see that the relationship between cultures has a relationship that is very closely related to tourism and the cultural environment which can provide added value to tourists who come to visit the place.We can also conclude that tourism and culture are activities of exchanging information and cultural symbols in which there are places, traditions, arts, ceremonies, and other identities contained in the place that can be enjoyed by every tourist who comes to visit.
\end{abstract}

Keywords: tourism development, cultural values, cultural environment.

\section{PENDAHULUAN}

Perkembangan sektor pariwisata ini di satu sisi memberikan keuntungan ekonomis yang cukup tinggi. Keuntungan ekonomis ini membawa pengaruh pada pendapatan negara secara umum dan kesejahteraan masyarakat sekitar secara khusus. Kehadiran wisatawan dapat diartikan sebagai kehadiran rezeki bagi sejumlah orang mulai para pemandu wisata, tukang becak, sampai dengan para pedagang. Dengan demikian, sektor pariwisata bukan sekedar memberikan keuntungan bagi pelaku-pelaku bidang pariwisata melainkan juga memberikan keuntungan sektor-sektor lain di luar pariwisata. 
Pariwisata budaya merupakan salah satu bentuk industri budaya, karena pariwisata budaya memanfaatkan berbagai aspek kebudayaan secara massal dalam suatu sistem produksi. Sebagai modal budaya (sumber daya), kebudayaan disejajarkan dengan sumber daya yang lain seperti sumber daya alam dan ekonomi (finansial). Salah satu kecenderungan global adalah tumbuhnya kesadaran wisatawan untuk memahami warisan budaya masa lalu. Hal itu untuk mencari ontensitas dan identitas budaya oleh wisatawan bersangkutan. Upaya untuk memahami warisan budaya masa lalu (cultural heritage) tidak hanya dilakukan dalam wilayah negara sendiri, akan tetapi juga lintas negara. Warisan budaya masa lalu dianggap sebagai modal (cultural capital) dalam pengembangan pariwisata budaya (Richards, 1999 dalam Ardika, 2008:209).

Pariwisata budaya ibarat pisau bermata dua dalam pemanfaatan warisan budaya sebagai objek daya tarik wisata. Di satu sisi pariwisata dapat melestarikan warisan budaya tersebut, sedangkan di sisi lain kegiatan pariwisata akan merusak atau berdampak negatif terhadap warisan budaya itu karena objek tersebut akan dikonsumsi oleh wisatawan (Burn dan Holden, 1995). Hal senada juga disampaikan pula oleh Eugenio Yunis (2006:1-5) bahwa pariwisata budaya dapat memberikan keuntungan ekonomi kepada masyarakat lokal, menghasilkan dana dan pendidikan untuk pemugaran atau konsevasi warisan budaya baik yang tangible maupun intangible, dan sekaligus menjadi ancaman yang sangat membahayakan apabila terjadi kesalahan pengelolaan pariwisata budaya tersebut. Lebih lanjut dikatakannya bahwa masyarakat lokal harus dilibatkan dalam perencanaan, implementasi/pelaksanaan, dan monitoring dari kegiatan pariwisata budaya.

Menurut UU nomor 10 tahun 2009 tentang kepariwisataan, daerah tujuan wisata yang selanjutnya disebut destinasi pariwisata adalah kawasan geografis yang spesifik berada dalam satu atau lebih wilayah administratif yang didalamnya terdapat kegiatan kepariwisataan dan dilengkapi dengan ketersediaan daya tarik wisata, fasilitas umum, fasilitas pariwisata, aksesibilitas, serta masyarakat yang saling terkait.

Dalam arti yang sangat luas, kebudayaan dapat dinyatakan sebagai keseluruhan masalahmasalah sepritual, material, segi-segi intelektual dan emosional yang beragam,dan memberi watak kepada suatu masyarakat atau kelompok sosial. Kebudayaan juga dapat pula diartikan sebagai segenap perwujudan dan keseluruhan hasil pikiran (logika), kemauan (etika), serta perasaan (estetika) manusia dalam rangka perkembangan pribadi manusia; hubungan manusia dengan manusia,hubungan manusia dengan alam, hubungan manusia dengan Tuhan (Bandem, 1995). Para ahli kebudayaan menekankan pentingnya aspek kebudayaan diperhitungkan dalam pencapaian tujuan pembangunan yang berkelanjutan. Kebudayaan menurut Koentjaraningrat (1990), adalah kebudayaan sebagai keseluruhan sistem gagasan tindakan dan hasil karya manusia dalam rangka kehidupan masyarakat yang dijadikan milik dirinya dengan belajar. Selanjutnya menurut Koentjaraningrat, ada tujuh unsur kebudayaan secara universal, yaitu; (1). Bahasa, (2). Sistem teknologi, (3). Sitem mata pencaharian atau ekonomi, (4). Organisasi sosial, (5). Sitem pengetahuan, (6). Religi, dan (7). Kesenian.

Indonesia adalah salah satu negara kepulauan yang terdiri dari beribu-ribu pulau besar dan kecil, dan pendukungnya terdiri dari kelompok-kelompok suku bangsa yang sangat beragam wujudnya. Jika dipandang dari sudut budaya, di Indonesia terdapat budaya-budaya yang sangat beragam (pluralistik), mulai dari adanya budaya lokal, suatu kebudayaan yang berlaku dalam lingkungan keluarga; kebudayaan daerah, suatu kebudayaan yang disepakati oleh daerah atau 
suku bangsa tertentu seperti kebudayaan Jawa, Banjar, Minang, Sunda, Bugis, Sasak, Dayak, Papua, Madura, dan sebagainya. Wawasan aneka budaya (multikultural) dalam dasawarsa terakhir ini banyak sekali ditampilkan dan dianjurkan dalam berbagai forum (Edi Sedyawati 2002), namun sebenarnya perlu disadari bahwa situasi aneka budaya itu tidak sama di semua negara, meskipun sama-sama mempunyai keanekaragaman budaya.

\section{METODE}

Metode penelitian yang digunakan adalah metode kualitatif dengan Strategi fenomenologi peneliti menggali data bagaimana mendeskripsikan mengenai Perkembangan pariwisata berwawasan lingkungan budaya yang meliputi beberapa aspek-aspek dalam meningkatkan kepariwisataan Indonesia yang mendorong pengembangan sektor-sektor lain baik secara langsung maupun secara tidak langsung.

\section{HASIL DAN PEMBAHASAN}

\section{Pengembangan Sektor Pariwisata}

Dalam kehidupan masyarakat modern, rekreasi merupakan kebutuhan hidup manusia yang tidak dapat dihilangkan lagi. Hal ini berkaitan erat dengan kesibukan hidup sehari-hari yang pada akhirnya membutuhkan penyeimbang berupa kesantaian dan refresing. Kebutuhan akan kesantaian dan refresing ini perlu mendapat jawaban berupa bisnis rekreasi dan hiburan, dalam hal ini sektor pariwisatalah yang berkepentingan.

Dari sisi lain, pengembangan sektor pariwisata mampu mendorong pengembangan sektor-sektor lain baik secara langsung maupun secara tidak langsung.Pengembangan kawasan pantai misalnya,akan mendorong pengembangan bidang transportasi baik berupa perbaikan jalan maupun route angkutan kendaraan umum. Perbaikan sarana jalan dan angkutan kendaraan umum mengakibatkan daerah di sekitarnya terbebas dari isolasi, yang pada akhirnya membawa pengaruh pada dinamika kehidupan penduduknya. Di samping itu, pengembangan sektor pariwisata membuka peluang bagi penduduk sekitarnya untuk meningkatkan taraf perekonomian melalui bisnis rumah makan maupun penginapan.

Dalam skala yang lebih besar, kesejahteraan dunia membawa pengaruh pada orangorang dari berbagai penjuru dunia untuk mengenal kebudayaan dari negara lain. Salahsatu caranya adalah dengan mengadakan perjalanan wisata. Keingintahuan ini menghasilkan keuntungan ekonimis berupa masuknya devisa pada keungan negara. Pada akhirnya, bisnis pariwisata memberikan keuntungan yang cukup besar dari berlapis bagi bangsa dan masyarakat.

Melihat sejumlah indikator di atas, pengembangan sektor pariwisata tampaknya menjadi sesuatu yang penting dan perlu mendapat perhatian khusus dari berbagai pihak. Karena jika sektor ini tidak mendapat perhatian khusus, mata rantai pencarian nafkat mulai dari para tukang becak, pemandu wisata, pengelola perjalanan wisata, sampai keuangan negara akan terpengaruh. Sebaliknya jika sektor ini pendapat perhatian khusus dan pada akhirnya sektor ini menjadi maju, banyak pihak yang diuntungkan.

\section{Wisata Budaya dalam Pariwisata}

Pengembangan pariwisata meliputi berbagai bidang. $\mathrm{Di}$ antaranya adalah pengembangan wisata alam (pantai, gunung, gua) dan pengembangan wisata budaya (upacara tradisional, pakaian tradisional, tari). Kedua bidang tersebut sama-sama memiliki daya tarik khusus bagi para wisatawan. Namun, jika kita mau mencoba mencermati kecenderungan para wisatawan khususnya wisatawan mancanegara, bidang yang menjadi daya tarik utama adalah 
bidang kebudayaan. Pariwisata alam tampaknya hanya menjadi "tempat beristirahat" bagi para wisatawan.

Ketertarikan wisatawan pada bidang budaya dapat diketahui dari berbagai indikator. Pertama, banyaknya wisatawan yang mengunjungi Kraton Yogyakarta. Keingintahuan wisatawan terhadap Kraton Yogyakarta dilandasi oleh keingintahuan akan pusat kebudayaan Jawa. Kedua, banyaknya wisatawan yang tertarik membeli benda-benda tradisional khas. Ketiga, banyaknya wisatawan yang tertarik mempelajari budaya khas seperti menari dan membatik. Keempat, banyaknya wisatawan yang tertarik dengan keramahtamahan kita dalam menanggapi mereka.

Dalam jangka panjang, bidang kebudayaan tampaknya akan lebih mendominasi motivasi wisatawan. Hal ini berkaitan erat dengan semakin langkanya nuansa tradisional di negara-negara maju.Karena kelangkaan tersebut, banyak orang ingin mengetahui bentukbentuk budaya asli nenek moyang mereka.

Jika sektor pariwisata budaya ini benar-benar dikelola oleh pemerintah, Yogyakarta akan mampu bersaing dengan negara-negara lain yang maju dan mempunyai komitmen untuk mengembangkan priwisata budaya seperti Korea dan Jepang. Namun, jika sektor ini justru tidak terperhatikan, dan fokus pengembangan hanya pada pariwisata alam, lama kelamaan para wisatawan akan bosan karena pada dasarnya pariwisata alam bersifat statis dan sekali datang.

Namun demikian, jika pengembangan pariwisata budaya ini dikembangkan dengan sembarangan, pengembangan pariwisata ini bisa menjadi bumerang atas kebudayaan itu sendiri. Eksploitasi besar-besaran terhadap pariwisata budaya akan mengakibatkan budaya tersebut kehilangan kualitasnya. Akibatnya, kebudayaan hanya sekedar simbol-simbol mati, tanpa makna.Pembisnisan budaya yang berlebihan juga akan mengaburkan hakikat dari kebudayaan itu sendiri. Pada akhirnya, kebudayaan tercabut dari asal-usulnya, yaitu masyarakat.

Pada sektor lain, pengembangan kebudayaan yang hanya diorientasikan pada pariwisata juga akan mengakibatkan para pelakunya terlalu "bisnis oriented". Bisnis oriented dalam bidang budaya atau komersialisasi budaya sebenarnya merupakan efek samping terjadinya transformasi budaya dalam proses pembangunan suatu negara. Menurut Suyatno Kartodirdjo (1992:145), ada empat masalah yang timbul sebagai akibat tranformasi budaya, yaitu masalah ketahanan budaya dan konflik nilai, masalah komersialisasi budaya, masalah materialisme dan konsumerisme, dan masalah konflik sosial.

Akibatnya, motivasi utamanya bukan lagi menunjukkan keluhuran budaya yang dimilikinya melainkan pada pertimbangan bisnis semata. Jika hal itu terjadi, kebudayaan bisa dimanipulasi demi kepentingan bisnis. Bahkan jika tidak diperhatikan secara sungguhsungguh hal itu akan mengakibatkan munculnya budaya baru yang tidak berakar pada kepribadian dan identitas bangsa. Transoformasi yang tidak berakar pada kedua hal tersebut akan menghasilkan budaya modern yang pada gilirannya akan menelan jenis budaya-budaya (tradisional) yang mempunyai nilai-nilai pencerminan kepribadian bangsa dan identitas bangsa (Kartodirdjo, 1992:146).

Dalam hubungannya dengan transformasi kebudayaan sebagai akibat pengembangan sektor pariwisata, ada baiknya disimak pendapat dari Sutan Takdir Alisahbana(Rahmanto, 1992:141). Beliau mengatakan bahwa transformasi budaya yang disebabkan oleh penerapan teknologi maju yang terlepas dari perspektif budaya bangsa akan mengakibatkan manusia dikuasai teknologi, dan bukan sebaliknya. 


\section{Pariwisata Berwawasan Lingkungan Budaya}

Permasalahan pokok yang kiranya perlu dicari jalan keluarnya adalah bagaimana kita mampu mengembangkan pariwisata yang berwawasan lingkungan budaya. Dalam hal ini ada beberapa hal yang sekiranya dapat dipertimbangkan sebagai alternatif pengembangan pariwisata berwawasan lingkungan kebudayaan.

Pertama, pembangunan fisik yang memperhatikan kekhasan Yogyakarta. Sebagai bagian dari kebudayaan Jawa, masyarakat Yogyakarta mengenal berbagai bentuk bangunan fisik. Dalam rangka menciptakan lingkungan budaya, fasilitas-fasilitas penunjang pariwisata seperti hotel, rumah makan, dan rumah penduduk sebaiknya mencerminkan bentuk bangunan khas Yogyakarta. Gedung-gedung bertingkat, rumah dengan bentuk atau corak barat, dan fasilitas perkantoran bergaya Barat sebaiknya dibatasi secara sungguh-sungguh. Dominasi gedung bertingkat dan rumah bergaya Barat mengakibatkan bentuk-bentuk fisik khas Yogyakarta menjadi pudar dan lama kelamaan hilang dengan alasan ekonomis (penghematan tempat).

Dalam kaitannya dengan mempertahankan kekhasan budaya Yogyakarta, ada baiknya kit simak pendapat dari P.J. Suwarno (1992). Beliau mengatakan bahwa Sultan yang memegang kekuasaan kharismatik, tradisional, dan legal-rasional menggunakan kekuasaan itu secara bijaksana untuk mentransformasikan Yogyakarta dari tradisional ke modern tanpa menghancurkan tradisi, tetapi menyeleksinya untuk dimanfaatkan dalam modernisasi Yogyakarta. Jika pendapat itu kita hubungkan dengan upaya mempertahankan bentuk fisik khas Yogyakarta, dapat dikatakan bahwa boleh jadi bentuk luarnya adalah bentuk khas Yogyakarta tetapi fasilitas dalamnya dikemas dalam nuansa modern.

Kedua, menghidupkan wisata budaya tradisional. Wisata tradisional yang dimaksudkan di sini adalah penyajian berbagai bentuk kebudayaan tradisional kepada para wisatawan. Bentuk-bentuk kebudayaan tradisional yang dimaksudkan antara lain jathilan, kirab pusaka, sekaten, dolanan bocah, dan upacara adat. Bentuk-bentuk kebudayaan ini sebenarnya memiliki daya tarik tinggi tetapi karena jarang dipertunjukkan secara rutin, para wisatawan kadang-kadang kesulitan menyaksikannya.

Ketiga, memberikan pendidikan budaya pada generasi muda. Sumber kemerosotan budaya sebenarnya bermula dari ketidaktahuan masyarakat akan pentingnya pemeliharaan kebudayaan bagi kelangsungan hidup sektor pariwisata. Akibat ketidaktahuan ini, banyak generasi muda justru mengikuti kebudayaan asing daripada memelihara kebudayaan sendiri. Sehingga, ketika mereka berhadapan dengan para wisatawan, yang dikedepankan adalah sikap dan perilaku yang meniru mereka, seperti berbicara dengan bahasa asing, berpakaian dengan gaya asing, dan bahkan berperilaku yang tidak sesuai dengan kebudayaan sendiri.

Slamet Sutrisna ( 1992:147) mengatakan bahwa perubahan kebudayaan tidak hanya melibatkan sistem normatif tetapi juga melibatkan sistem kognitif. Dalam hubungannya dengam masyarakat Indonesia yang sedang membangun, budaya keilmuan harus dikembangkan sebagaimana mestinya. Dengan demikian, pengembangan dan pelestarian lingkungan budaya perlu dihubungkan dengan proses pendidikan bagi generasi penerusnya.

Keempat, penghargaan terhadap warisan nenek moyang. Warisan nenek moyang kita berupa tosan aji, gebyog, perabot tradisional, dan barang antik lainnya tampaknya semakin merosot seiring dengan maraknya bisnis barang antik. Banyak sekali perabot tradisional yang diperjualbelikan dan diekspor ke luar negeri. Keuntungan ekonimisnya memang cukup besar, namun kita kehilangan barang-barang warisan nenek moyang. Padahal barang-barang seperti itu juga memiliki nilai sejarah dan memiliki daya tarik pariwisata. Jika pada akhirnya benda- 
benda seperti itu habis berpindah ke luar negeri, pariwisata kita akan kehilangan obyek yang bisa dipromosikan.

Kelima, pengalokasian dana untuk pengembangan kebudayaan. Dalam hubungannya dengan anggaran pembangunan, anggaran pembangunan sarana fisik tampaknya masih menjadi perhatian utama dan menyerap banyak sekali dana. Padahal, pengembangan sarana fisik inilah yang secara langsung menghancurkan lingkungan budaya masyarakat tertentu. Munculnya hotel megah di antara rumah penduduk membawa akibat berubahnya budaya masyarakat sekitarnya. Alangkah baiknya jika dalam waktu mendatang pengalokasian dana untuk pengembangan kebudayaan ditambah atau diperbesar. Masyarakat tradisional sebenarnya masih ingin memainkan jathilan, tayub ataupun slawatan. Namun karena terbentur pada masalah anggaran mereka tidak mampu mengembangkan kebudayaan itu. Jika tersedia anggaran, niscaya mereka akan dengan senang hati mengadakan pertunjukan jathilan secara rutin, mereka akan senang hati mengadakan pertunjukan tayub secara rutin. Apalagi jika para pelaku budaya tersebut mendapat insentif berupa uang lelah atas pentas mereka.

\section{Membangun Pariwisata Melalui Nilai Budaya}

Persoalan kompleks disekitar pembangunan bangsa dapat kita pahami bersama yaitu persoalan daya guna, keadilan, dan kesejahteraan yang belum merata. Ada kelemahan yang mewarnai konsep pembangunan yang menekankan pertumbuhan ekonomi yang tinggi dan konsep tricking down effect (Tjatra, 2004), dan muncullah berbagai konsep pembangunan alternatif, seperti ecodevelopment dan sustainable development. Pendekatan ekologi ecodevelopment memandang keberlanjutan pembangunan dari sudut sejarah kebudayaan masyarakat tertentu, keterampilan yang dimiliki oleh masyarakat biasa, ethno-ecology, dan keadaan alam yang mewarnai ecosistem setempat dalam rangka memenuhi kebutuhan manusia yang tinggal dalam lingkungannnya.

Budaya modern membedakan dan menyepakati berbagai hubungan politik,ekonomi, budaya antara saat ini dan masa depan (Tian Feng, 1999), untung dan rugi lewat perubahan hari ini dan besok dari strategi berlawanan. Oleh sebab itu, uji coba penting saat ini adalah, memberikan masyarakat mempelajari dan menganalisa "modern dan tradisional", "seni dan teknologi", "jiwa dan tubuh", "materi dan ruh", dari sisi positif dan negatif sains dan teknologi modern. Karena lewat jalan berlawanan kita akan melihat dengan jelas keindahan dan keburukan, kebaikan dan kejelekan, tinggi dan rendah, puas dan serakah, jauh dan dekat, untung dan rugi, dan lain-lain, untuk mengetahui segalanya. Manifesto kebudayaan pluralistik juga merupakan salah satu dari kebudayaan tradisional, demikian juga manifesto ekonomi dan politik pluralistik. Dengan demikian persentuhan antar budaya tidak saja melampaui batasbatas geografis, tetapi juga bersilangan dalam dimensi waktu - bergerak kemasa lampau dan masa depan.

\section{Perkembangan Pariwisata Budaya}

Banyak pakar budaya yang menganggap bahwa industri pariwisata berdampak kurang baik, bahkan merusak perkembangan seni pertunjukan di negara berkembang (Soedarsono,1999). Industri pariwisata dikatakan merusak, mendesakralisasikan, mengkomersialisasikan seni pertunjukan tradisional, dan sebagainya. Lebih lanjut Soedarsono dalam hasil penelitiannya, bahwa dalam menilai kemasan seni pertunjukan wisata digunakan teori serta konsep yang benar dan cocok, jelas industri pariwisata memperkaya perkembangan seni pertunjukan Indonesia Kebudayaan ekspresif, seperti tarian, musik, dan teater, sekarang ini menjadi bentuk-bentuk hiburan dan komoditi komersial. 


\section{Menghormati Keragaman dan Komunitas Budaya sebagai upaya Pelestarian Pariwisata.}

Secara umum, tradisi-tradisi budaya di Indonesia mengutamakan keselarasan hubunganhubungan orang-perorang dalam masyarakat yang dilandasi prinsip-prinsip rukun dan hormat (Soehardi, 2001:3-26). Artikulasi keselarasan itu berbeda dari masyarakat suku bangsa satu dengan lainnya, tetapi prinsip-prinsip kerukunan yang diwujudkan dalam aktivitas gotongroyong dapat dijumpai di semua suku bangsa yang ada di Indonesia. Perjalanan perkembangan suatu kebudayaan dan masyarakat dalam sejarahnya tidak pernah tertutup dari persinggungan budaya-budaya lain. Dimana kontak-kontak budaya regional, atau antar benua sudah berlangsung dari zaman awal sejarah samapi sekarang (melalui perkembangan komunikasi global seolah-olah antar budaya kini menjadi tanpa batas). Kalau dilihat dari teori evolusi, maka perubahan-perubahan yang terjadi tersebut dapat dipandang sebgai suatu "progress" yang sejalan dengan proses evolusi dari masyarakat tradisional ke masyarakat modern. Dengan demikian proses perubahan semacam ini dapat dialami hampir semuan bangsa-bangsa di dunia, termasuk suku-suku bangsa di Indonesia; Jawa, Bali, Sunda, Minang, Batak, dan yang lainnya.

Kontak masyarakat Bali dengan budaya luar bukan sesuatu hal baru, karena telah terjadi ribuan tahun yang lalu. Hal ini dapat dilihat dari adanya berbagai "pengaruh luar" dalam adat budaya Bali, seperti pengaruh India, Cina, Arab dan - tentu saja - Jawa (MPLA, 1991; Mantra, 1993; Barth, 1993, dalam Pitana, 1994:156-157). Selanjutnya intensitas kontak kebudayaan Bali dengan kebudayan luar meningkat secara dramatik pada paruh kedua abad ini, yang terkait erat dengan adanya perkembangan teknologi yang pesat dibidang komunikasi dan transportasi, serta keberhasilah Bali menjadikan dirinya sebagai daerah tujuan wisata yang terkenal di dunia (ibid, 157). Dari prespektif sejarah, kebudayaan Bali memiliki keterbukaan dengan kebudayaan luar dan memperlihatkan sifat fleksibel dan adaptif. Potensi ini penting artinya untuk menghindari perbenturan antar budaya. Jika dilihat dari tatanan sejarah nasionalisme Indonesia, juga dapat dipahami bahwa konsep wawasan kebangsaan adalah "persatuan dan kesatuan". Seperti dari pernyataan Presiden Soeharto, pada Dharma Santi Penyepian 1997, dalam Dewa Atmaja (2002), "bahwa dari kenyataan keanekaragaman suku bangsa, adat istiadat dan budaya di Indonesia yang penting bukan masing-masing suku, bahasa, atau budayanya, akan tetapi keseluruhan suku bangsa, adat-istiadat, budaya,

\section{KESIMPULAN}

Gagasan tentang warisan cultural dipandang sebagai aspek penting yang harus dilindungi dalam rangka mencari identitas nasional dilandasi oleh hasrat sederhana untuk mengabdikan kegemilangan masa silam. Sebagaimana disebutkan di muka, pluraristik (keragaman) budaya khususnya seni pertunjukkan yang dimilikinya dapat sebagai sumber daya dalam pembangunan pariwisata berwawasan budaya.

Selama ini berbagai paguyuban etnis Nusantara yang terdapat di Bali khususnya Denpasar memiliki potensi budaya asalnya namun keberadaannya antara hak dan kewajiban sebagai warga masyarakat belum bisa dirasakan, sehingga keragaman budaya khususnya seni pertunjukan daerahnya belum terjamah dan dimanfaatkan secara maksimal dalam mendukung pembangunan pariwisata berwawasan budaya.

Dengan demikian perlu adanya interaksi dan dialog-dialog yang intensif antara paguyuban etnis nusantara dengan lembaga formal khususnya pemerintah daerah dan organisasiorganisasi sosial lainnya seperti sanggar seni, sekaa-sekaa guna mendukung visi dan misi pembangunan daerah yang berwawasan budaya. 


\section{DAFTAR PUSTAKA}

Arbani. (2001). Pengelolaan Perjalanan Wisata. Yogyakarta: Pustaka Baru Press.

Badaruddin. (2020) Membangun Kearifan Lokal Menuju Distinasi Pariwisata Internasional. Jakarta: Renika Cipta.

Darwati. (2017). Manajemen Perjalanan Wisata Budaya. Yogyakarta: Aswaja Pressindo

Kartodirdjo, Suyatno. (1992). “Tranformasi Budaya dalam Pembangunan” dalam Tantangan Kemanusian Universal. Yogyakarta: Kanisius

Ngalimun \& Harun, Makmur. (2020). Komunikasi Bahasa Jawa dalam bentuk Sapaan Keluarga Transmigrasi di Kalimantan, Indonesia. PENDETA: Journal of Malay Language, Education and Literature, 11(2), 108-125. https://doi.org/10.37134/pendeta.vol11.2.9.2020

Rustono. (2000). Tahta Untuk Rakyat: Celah-celah Kehidupan Sultan Hamengkubuwono IX. Jakarta: Gramedia.

Sutrisna, Slamet. (1992). "Budaya Keilmuan dan Situasinya di Indonesia” dalam Tantangan Kemanusiaan Universal. Yogyakarta: Kanisius.

Suwarno, P.J. (1992). "Belajar dari Sejarah Yogyakarta untuk Memasuki Era Globalisasi" dalam Tantangan Kemanusiaan Universal. Yogyakarta: Kanisius.

Tantri, Turyati. (2011). Ayo ke Yogyakarta: Yogyakarta Kota Wisata. Yogyakarta: K-Media. 